\title{
The Use of Dialogue Journal Writing to Improve English Language Learners' Writing Skill
}

\author{
Lizamaria Raphael Parrikal, Nur Ehsan Bin Mohd Said
}

\begin{abstract}
Dialogue journal writing is a tool utilised in the teaching of writing that allows teachers to provide feedback and responses to students' writing in a non-corrective manner. It is believed that this teaching tool can improve students' overall writing ability. Over a span of 20 years of published studies, this systematic review will examine the effectiveness of dialogue journal writing on English language learners' overall writing skills. A total of 692 English language learners (ELLs) in 1997 to 2019 are represented in the analyses across 19 studies; seven cases of action research, one case study and eleven experimental studies. Findings suggest that ELLs benefit from dialogue journal writing in terms of specific English writing skills both academically and socially. Implications for further study and practice are also discussed.
\end{abstract}

Keywords: Dialogue Journals, Writing Skills, English Language Learners, Systematic Review

\section{INTRODUCTION}

What makes writing one the most complex tasks for ESL learners is the content development that relies heavily on the strength of the other language skills; reading, listening and to a certain extent, speaking. In addition, learners of any second language are usually least exposed to writing as they are surrounded by various forms of media that enable them to read, listen occasionally speak and write. However, writing is often avoided in day-to-day interactions. Many sub-skills of writing must be employed effectively to develop good compositions; these include, accurate use of spelling and register, correct grammar, register, and most importantly content organisation. Students in Malaysia are taught English mainly to provide them with the opportunity to utilise the language as tool to communicate in everyday life, for the purpose of furthering their studies and career building [26].

\section{A. Research Background}

The basic educational landscape of Malaysian students to English as a second language is comprised of 6 compulsory years of primary education and 5 years of secondary education. Under the new standardised curriculum for secondary education (KSSM), English is taught for 2.6 hours per week which amounts to 112 hours per year. Depending on the allocation for each period at different schools, either 35 or 40 minutes per period, students learn English for 5 or 6

Revised Manuscript Received on May 15, 2020.

* Correspondence Author

Lizamaria Raphael Parrikal*, Sekolah Menengah Kebangsaan Indahpura (1), Universiti Kebangsaan Malaysia, Bangi, Malaysia. Email: lizamariaparrikal@gmail.com

Nur Ehsan Bin Mohd Said, Faculty of Education, University Kebangsaan Malaysia, Bangi, Malaysia.. Email: nurehsan@ukm.edu.my

(C) The Authors. Published by Blue Eyes Intelligence Engineering and Sciences Publication (BEIESP). This is an open access article under the CC BY-NC-ND license (http://creativecommons.org/licenses/by-nc-nd/4.0/) periods each week [26]. Within these hours, there are four skills required to be taught and practised; reading, listening, writing and speaking.

Writing assessment in the Malaysian ESL classroom has also undergone a revamp. In 2019, the Common European Framework of Reference (CEFR) was introduced. Where previously many teachers were at liberty to focus on reading and writing in the English classroom (as these carried a higher weightage towards an overall grade), the recent changes in the curriculum have placed equal weightage on all four skills for the standardised tests in Form 3 (age 15), otherwise known as Pentaksiran Tingkatan Tiga (PT3). Instead of being able to focus on 2 primary skills, teachers must now equally distribute the limited time allocated to cover all the four skills.

\section{B. Statement of the Problem}

Operational proficiency is the aspired goal set by the Ministry of Education Malaysia. Nevertheless, [8] found that the quality of English among Malaysian students especially in writing was on a steady decline despite having learnt English throughout 11 years of formal schooling. [13] suggested that the main cause of challenges that ESL learners faced in their writing was due to poor English language proficiency.

These statistics render the current methods of teaching writing debatable. [31] implied that students' weakness in mastering English despite studying it for 11 years is still a topic of concern among educationists. This inability to efficiently use the language is seen as a shortcoming causing a high level of unemployment among graduates. At a classroom level, teachers are being encouraged to explore various non-conventional methods to accustom students to the writing process. Dialogue journal writing is seen as one such method, as it encourages writer-reflection, expression and communicative learning. Another possible cause of this aversion towards writing could be a strict focus on form that deters students who are weaker in the language. Despite efforts to guide and model the teaching of English according to the CEFR, motivation and fluency in writing need to be honed and polished separately.

Many educators are guilty of ignoring content formulation in favour of the rigid format- based teaching. The teaching of writing should allow for expression of ideas, opinions and views that may or may not concur with mainstream views. Van De Weghe (2008) believes that the writing process can become stunted or restricted through an over-reliance on formulaic approaches to teaching writing. While the assessment-based system is necessary as a yardstick to overall improvement, it is believed that classroom practices in the teaching of writing should be adapted and modified to encourage, ease and lower the anxiety related to writing.

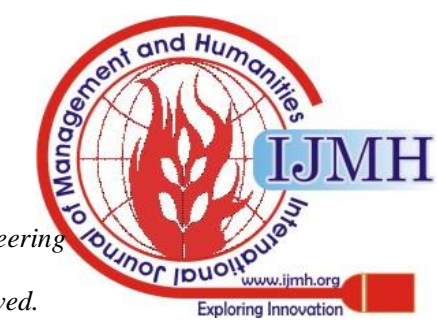




\section{LITERATURE REVIEW}

\section{A. Writing Skills}

[30] define writing as an intricate skill that comprises writing visible signs or graphic symbols on a flat surface to convey meaning, hence, making it a system for interpersonal communication. This is further synthesized to mean writing is the ability to produce meaningful information understood by its intended reader while being coherent and developed. Below are the definitions and conceptualisations of writing sub-skills

\section{B. Dialogue Journal Writing Overview}

Dialogue journals are communicative entries written in response to a topic provided or one that students are interested in. Dialogue journals refer to a written correspondence whereby there exists a continuous communication between teacher and learner. While students are at liberty to write as much or as little as they want, the teacher responds by answering questions, commenting and introducing topics or new questions [15]. Dialogue journaling which operates as a two-way communication between the student and the teacher provides opportunity for constant response and serves as a tool of guidance for students. This view is shared by [6] who claims that dialogue journals provide constant low-stress exercise in writing whereby learners can express themselves liberally as well as observe models of quality writing. Features and benefits of dialogue journal writing include its ability to create a meaningful teaching and learning experience [27], act as a bridge between student and teacher [40], provide learners opportunities to express voice [14], act as a means of opening and maintaining ongoing communication between teacher and students [20] and teach communication in addition to writing [36]. Dialogue journal writing has been implemented in studies with focus on improving a range of aspects such as fluency [37], descriptive or narrative text and recount writing [5]; [4]; [29]), word choice and vocabulary [1] content and idea development ([11];[7]), syntactic complexity and proficiency ([19]; Chan, 2005), grammar and form [23].

Studies in dialogue journal writing have also focused on non-academic features such as writing anxiety and motivation [22] as well as apprehension [35]. In addition, there have been studies applying technology such as Whatsapp and Email into dialogue journal writing implementation ([1; [38]; [33]). Research in the area of dialogue journal writing encompass normal as well as gifted learners [38]. It has proven effective in non-native speakers and primarily focused on English as a foreign language (EFL) learners ([19]; [5];[1]; [22]; [24] )and a few on English as a second language (ESL) learners ([37]; [23]). Many of the studies on dialogue journal writing were conducted at tertiary education level, with university or college level participants ([11]; [32]; [12]; [35]) while a few were concentrated on high school students ([14]; [25])

\section{Writing and the Socio-Cultural Theory}

Writing is a method of communication which makes it a social process. The training of writing that is not productoriented but draws on the cognitive processes that are at work during the development stages. This systematic review will be grounded within the socio-cultural theory of learning writing that advocates guidance and feedback as an important tool for learning. As described in [3], this theory was first conceptualized by L.S Vygotsky who theorized that the socio-cultural view is the center of learning and communication process. [28] found that writing has undergone a shift from the view that it is mainly a thinking process, to a more social and motivational context. Thus, dialogue journal writing is a viable instrument to facilitate the interaction between learner and teacher to create a more comprehensive learning experience.

\section{Dialogue Journals as a teaching Tool}

[17] discovered that dialogue journal writing yielded a method to bond with students with behavioural issues and social challenges. Apart from this apparent bond, limitations in grammar were easily addressed by the teacher without the pressure of restricting content, format and points. According to [16], learners are first motivated in writing to express opinions about their readings, secondly they are presented the chance to employ the language learnt in real situational context and thirdly, the feedback can be subjectively given according to each student's needs. Similarly the findings in [39] concur as they describe the journal writing process as a pedagogical undertaking that not only allows an ESL teacher to keep abreast with the growing demands of teaching but also links reading with the writing process. Thus, journaling is a very feasible supplement to any English lesson.

\section{E. Dialogue Journals to Improve Writing}

In their research on African American 4th grade students by Haynes-Mays, Broussard and Peltier-Glaze (2011), it was found that dialogue journals not only provided a new avenue for communication, but also allowed for another aspect for literacy development. This phenomenon was because students were able to utilize the English language with a proficient speaker in a non-threatening atmosphere. In contrast to regular classroom writing tasks that are assessed by teachers, dialogue journaling provides the all-important communication factor of feedback, reaction and response that is missing in regular homework assignments. Dialogue journal writing has been implemented in schools in an effort to improve students writing fluency and confidence. In their research on dialogue journaling, [22] discovered that dialogue journal writing promoted the students' writing proficiency based on their results on a pre-test and post-test.

\section{PURPOSE OF THE SYSTEMATIC REVIEW}

The purpose of this review is to expand on the available literature on the effectiveness of dialogue journal writing to improve writing skills of English Language Learners. This work will summarise and organise previous studies conducted that have employed dialogue journal writing to generate a wholistic picture of the evidence in the area. This is needed in order to direct future research efforts in the area. The purpose of this systematic review is to attempt to clear any uncertainty about the effectiveness of this method of intervention where there has been previous research. The results for each study will be summarised and interpreted.

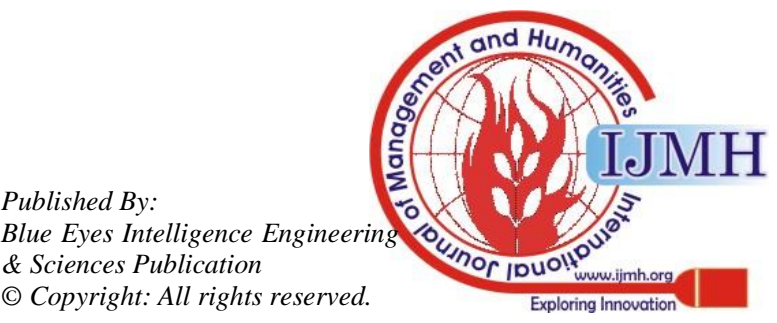


As they are reported, this review will address any gaps in the dialogue journal writing literature by providing needed information on the effectiveness in secondary level and college or university level English language learners.

\section{METHOD}

International online bibliographic databases such as Google Scholar, Web of Science, Educational Resources Information Centre (ERIC), JSTOR, and SAGE were used to identify research studies or articles written in English published between years 1980 and 2019 (research carried out over the past thirty nine years). The search terms used to search for the past related studies in the keywords fields of the above databases were "dialogue journaling", "dialogue journal writing" and "improve writing skills" and "ESL learners" "EFL learners". The initial search yielded 200 results. Later, the title and abstract of these studies were screened with regard to the inclusion criteria as following; (a) included participants or respondents from any school or tertiary education level; (b) studies conducted in teaching English as second language (ESL) or teaching English as a foreign language (EFL) context; (c) studies that examine the effects of dialogue journal writing on ESL students' writing skills. A total of 21 studies that met the selection criteria were included in this systematic review. As proposed by [21], the procedure involving three stages and seven activities were adopted to conduct this review. The first stage, i.e. planning the review was carried out to identify the need for a review and develop the review protocol. The next stage, conducting the review to identify relevant research that explored the usage of dialogue journal writing as a tool to improve ESL learners' writing skill so that primary studies could be selected to extract and synthesise the data. The third stage was then carried out to report the review whereby the results of relevant studies are summarized but not statistically combined.

Table I: Summary of studies on the use of dialogue journal writing to improve academic outcomes

\begin{tabular}{|c|c|c|c|c|c|c|c|c|}
\hline & Article/study & $\begin{array}{c}\text { No/type of } \\
\text { Participants }\end{array}$ & $\begin{array}{l}\text { Research } \\
\text { design }\end{array}$ & Type of Intervention & Focus of improvement & Instruments & $\begin{array}{l}\text { Interventio } \\
\text { n period }\end{array}$ & Results \\
\hline 1. & Stone, 2019 & 19 & $\begin{array}{l}\text { quasi- } \\
\text { experimental }\end{array}$ & $\begin{array}{l}\text { Simultaneous Dialogue } \\
\text { journal writing and peer } \\
\text { feedback }\end{array}$ & $\begin{array}{l}\text { English fluency among college } \\
\text { level ESL students }\end{array}$ & $\begin{array}{l}\text { 1. observation } \\
\text { 2. dialogue journal entries }\end{array}$ & 3 months & $\begin{array}{ll} & 14 \text { out of } 19 \text { students }(64 \%) \text { improved on } \\
\text { grammar } \\
16 \text { out of } 19 \text { students (84\%) improved } \\
\text { their spelling } \\
\text { Students became more confident with } \\
\text { English use and overall English fluency } \\
\text { increased }\end{array}$ \\
\hline 2. & $\begin{array}{l}\text { Fatoni, } 2019 \\
\text { Indonesian }\end{array}$ & 40 & action research & $\begin{array}{l}\text { Directed dialogue journal } \\
\text { writing }\end{array}$ & $\begin{array}{l}\text { English writing skills (news } \\
\text { items) }\end{array}$ & $\begin{array}{l}\text { Pre-test } \\
\text { post test }\end{array}$ & & $\begin{array}{l}92 \% \text { of participants showed } \\
\text { improvement in writing content at the } \\
\text { end of the study }\end{array}$ \\
\hline 3. & $\begin{array}{l}\text { Johnson \& } \\
\text { Cheng, } 2019\end{array}$ & 45 & $\begin{array}{l}\text { independent } \\
\text { experimental }\end{array}$ & $\begin{array}{ll}\text { 1. } & \begin{array}{l}\text { Dialogue journal } \\
\text { writing }\end{array} \\
\text { 2. } & \text { Error corrected } \\
\text { feedback }\end{array}$ & $\begin{array}{l}\text { Writing proficiency among } \\
\text { Japanese EFL learners }\end{array}$ & $\begin{array}{l}\text { questionnaire } \\
2 \text { native raters }\end{array}$ & 14 weeks & $\begin{array}{l}\text { DJW proved more effective that ECF for } \\
\text { improving overall writing ability } \\
\text { ECF was more effective for improving } \\
\text { vocabulary usage }\end{array}$ \\
\hline 4. & $\begin{array}{ll}\text { Pane, } & \text { Oktora } \\
\& & \text { Novita, } \\
2018 & \end{array}$ & 25 & $\begin{array}{l}\text { action research } \\
\text { (qualitative) }\end{array}$ & $\begin{array}{l}\text { Reflective dialogue } \\
\text { journal writing (personal } \\
\text { concern on their } \\
\text { academic writing) }\end{array}$ & students' ability in writing & $\begin{array}{l}\text { needs assessment } \\
\text { questionnaire } \\
\text { dialogue journal entries }\end{array}$ & 1 semester & $\begin{array}{l}\text { Students were more inclined to share } \\
\text { insights, opinions, anecdotes } \\
\text { Students could reflect and focus on their } \\
\text { writing process and stumbling blocks }\end{array}$ \\
\hline 5. & Janah, 2018 & 38 & $\begin{array}{l}\text { quasi- } \\
\text { experimental }\end{array}$ & $\begin{array}{l}\text { dialogue journal writing } \\
\text { (based on lessons \& } \\
\text { academic activity) }\end{array}$ & writing ability & & 1 month & $\begin{array}{l}20 \% \text { increase in participants who } \\
\text { obtained score ranging from good - } \\
\text { excellent } \\
53 \% \text { increase in students who } \\
\text { participated actively in group activity }\end{array}$ \\
\hline 6. & $\begin{array}{l}\text { Darmayenti, } \\
2018\end{array}$ & 30 & experimental & $\begin{array}{l}\text { dialogue journal writing } \\
\text { (theme: Local legends in } \\
\text { Indonesia) }\end{array}$ & writing ability & & 7 weeks & $\begin{array}{l}\text { Students' mean scores for components } \\
\text { of writing including content, } \\
\text { organisation, vocabulary, language use, } \\
\text { mechanics improved from } 52.64 \text { in the } \\
\text { pre-test to } 81.44 \text { in the post test. }\end{array}$ \\
\hline 7. & $\begin{array}{l}\text { Dabbagh, } \\
2017\end{array}$ & 84 & experimental & $\begin{array}{l}\text { Dialogue journal writing } \\
\text { (free topics) }\end{array}$ & Descriptive writing performance & $\begin{array}{l}\text { Oxford Quick Placement Test } \\
\text { (2004) }\end{array}$ & 6 months & $\begin{array}{l}\text { Significant difference between } \\
\text { experimental and control group in terms } \\
\text { of overall writing ability, and } \\
\text { subcomponents of content, organisation } \\
\text { and vocabulary } \\
\text { No significant effect of dialogue journal } \\
\text { writing in subcomponents of language } \\
\text { use and mechanics }\end{array}$ \\
\hline 8. & $\begin{array}{l}\text { Desiyana, } \\
2016\end{array}$ & 32 & Action research & Dialogue journal writing & Writing Skill & $\begin{array}{l}\text { Pre-test } \\
\text { post test }\end{array}$ & 1 month & $\begin{array}{l}\text { The mean score of the post-test } \\
\text { compared to the pre-test improved from } \\
60.62 \text { to } 66.25 \\
\text { In the second post -test the mean score } \\
\text { improved further to } 74.37\end{array}$ \\
\hline 9. & $\begin{array}{l}\text { Alsaleem, } \\
2013\end{array}$ & 30 & $\begin{array}{l}\text { quasi- } \\
\text { experimental } \\
\text { action research }\end{array}$ & $\begin{array}{l}\text { Dialogue Journal writing } \\
\text { through "WhatsApp" }\end{array}$ & $\begin{array}{l}\text { Writing Skills: Vocabulary, } \\
\text { Word Choice and Voice }\end{array}$ & $\begin{array}{l}\text { pre -test and post test } \\
\text { WhatsApp journal entries }\end{array}$ & 6 weeks & $\begin{array}{l}\text { Electronic journaling is a tool that } \\
\text { significantly helps students develop their } \\
\text { voice and improve the vocabulary word } \\
\text { choice in their writing. } \\
\text { Instructors could spot students that need } \\
\text { work in improving the specific skills of } \\
\text { voice and vocabulary word choice and } \\
\text { incorporate electronic dialogue } \\
\text { journaling into an individualized } \\
\text { assignment for them to help improve } \\
\text { those skills }\end{array}$ \\
\hline
\end{tabular}




\section{The Use of Dialogue Journal Writing to Improve English Language Learners' Writing Skill}

\begin{tabular}{|c|c|c|c|c|c|c|c|c|}
\hline 10. & $\begin{array}{l}\text { Foroutan, } \\
\text { Noordin \& } \\
\text { Hamzah, } \\
2013\end{array}$ & 40 & $\begin{array}{l}\text { quasi- } \\
\text { experimental }\end{array}$ & $\begin{array}{ll}\text { 1. } & \text { Topic based writing } \\
\text { 2. Dialogue Journal } \\
\text { Writing }\end{array}$ & $\begin{array}{l}\text { Writing skills: Content, } \\
\text { Organisation, vocabulary, } \\
\text { Mechanics, Language use }\end{array}$ & pre test post test & 10 weeks & $\begin{array}{l}\text { Mean score for the Dialogue journal } \\
\text { group increased from } 63.59 \text { to } 70.14 \\
\text { Mean score for the Topic based writing } \\
\text { group increased from } 62.59 \text { to } 68.91 \\
\text { DJW outperformed TBW in } 2 \text { aspects: } \\
\text { Content and Vocabulary } \\
\text { TBW outperformed DJW in } 2 \text { aspects: } \\
\text { Organisation and Language use. }\end{array}$ \\
\hline 11. & $\begin{array}{l}\text { Basiswi \& } \\
\text { Wulyani, } \\
2013\end{array}$ & 49 & $\begin{array}{l}\text { quasi- } \\
\text { experimental }\end{array}$ & Dialogue Journal Writing & Narrative Writing skills & $\begin{array}{l}\text { Pre-test post test } \\
\text { questionnaire }\end{array}$ & 1 month & $\begin{array}{l}\text { The difference of the pre-test score and } \\
\text { post-test score of the experimental group } \\
\text { was } 12.02 \text { points, while the difference of } \\
\text { the pre-test score and post-test score of } \\
\text { the control group was } 4.78 \text { points. }\end{array}$ \\
\hline 12. & $\begin{array}{l}\text { Muflikhati, } \\
2012\end{array}$ & 25 & Action Research & Dialogue Journal Writing & Writing Skills (Recount texts) & $\begin{array}{l}\text { observation } \\
\text { pre-test post-test } \\
\text { dialogue journal entries } \\
\text { interview }\end{array}$ & 6 weeks & $\begin{array}{l}\text { The students mean score in the aspect of } \\
\text { grammar improved from } 2.73 \text { to } 3.8 \text { in } \\
\text { the post-test } \\
\text { In the aspect of vocabulary, students } \\
\text { improved from } 3.08 \text { to } 3.76 \text { in the post- } \\
\text { test } \\
\text { Participants improved din terms of } \\
\text { mechanics from } 2.56-3.6 \text { in the post- } \\
\text { test } \\
\text { In terms of fluency, participants scored } \\
2.56 \text { and improved to } 3.64 \text { in the post- } \\
\text { test } \\
\text { In terms of organisation, participants } \\
\text { improved from } 2.82 \text { to } 3.56 \text { in the post- } \\
\text { test. }\end{array}$ \\
\hline 13. & $\begin{array}{l}\text { Rezaei \& } \\
\text { Manzari, } \\
2011\end{array}$ & 4 & Case Study & $\begin{array}{l}\text { Dialogue Journal Writing } \\
\text { via email correspondence } \\
\text { with native speakers } \\
\text { (topics provided) }\end{array}$ & $\begin{array}{l}\text { writing quality and writing } \\
\text { quantity }\end{array}$ & dialogue journal entries & 7 weeks & $\begin{array}{l}\text { the data reveals an improvement in } \\
\text { overall effectiveness of the participants' } \\
\text { writing skill } \\
\text { the Mean for the students had the highest } \\
\text { improvement in the content of the } \\
\text { writings } \\
\text { The least improvement was seen in the } \\
\text { category of Language } \\
\text { An improvement was observed in } \\
\text { participant's ability to write longer } \\
\text { entries over time. } \\
\text { The number of words in the students' } \\
\text { dialogue journals does not increase } \\
\text { steadily from the first to the last entry } \\
\text { and this finding can be attributed to the } \\
\text { writing topics. }\end{array}$ \\
\hline 14. & Sigmon, 2016 & 13 & Exploratory & Dialogue Journal Writing & Literacy Transactions & $\begin{array}{l}\text { dialogue journals } \\
\text { motivation inventories } \\
\text { field notes (observations) }\end{array}$ & 10 weeks & $\begin{array}{l}\text { Results showed evidence that dialogue } \\
\text { journals provided a space, which } \\
\text { encouraged students to transact with } \\
\text { others about content } \\
\text { Findings showed evidence of students } \\
\text { writing more when they were responding } \\
\text { to their classmate than to the teacher } \\
\text { which highlighted evidence of a change } \\
\text { in the authenticity of student responses } \\
\text { based on whether the journal audience } \\
\text { was their partner or the teacher. } \\
\text { Dialogue journals allowed all students to } \\
\text { communicate with others about content } \\
\text { in a way that did not draw attention to } \\
\text { any student } \\
\text { dialogue journals could be used as a } \\
\text { means of data collection regarding } \\
\text { students' understandings of content } \\
\text { knowledge as well as an informal } \\
\text { diagnostic tool for writing, grammar, } \\
\text { and spelling needs }\end{array}$ \\
\hline 15. & $\begin{array}{l}\text { Mehrdad, } \\
2008\end{array}$ & 50 & Experimental & Dialogue journal writing & Writing skills & & 4 months & $\begin{array}{l}\text { students in the experimental group had a } \\
\text { better performance as far as fluency and } \\
\text { grammar were concerned, but their } \\
\text { performance was much the same as } \\
\text { those in the control group on } \\
\text { organisation and punctuation. }\end{array}$ \\
\hline 16. & $\begin{array}{l}\text { Ghajar \& } \\
\text { Mirhosseini, } \\
2005\end{array}$ & 30 & $\begin{array}{l}\text { Ethnographic } \\
\text { research } \\
\text { (qualitative) }\end{array}$ & Dialogue Journal Writing & EFL literacy & $\begin{array}{l}\text { journal entries } \\
\text { written interview }\end{array}$ & 8 months & $\begin{array}{l}\text { In the context of Empowerment, the } \\
\text { results showed dialogue journals were } \\
\text { used by students to speak out and } \\
\text { express dissatisfactions hence playing a } \\
\text { major role in empowering them. } \\
\text { As for the aspect of development of } \\
\text { critical literacy, analysis of the journal } \\
\text { entries revealed a shift from descriptive } \\
\text { and personal entries to critical and } \\
\text { creative showing a transformation in } \\
\text { students' vew of writing. } \\
\text { The study indicates dialogue journals }\end{array}$ \\
\hline 17. & Kim, 2003 & 14 & $\begin{array}{l}\text { Action Research } \\
\text { (qualitative) }\end{array}$ & & $\begin{array}{l}\text { Learners' language development } \\
\text { and literary responses }\end{array}$ & $\begin{array}{l}\text { Dialogue journals } \\
\text { survey } \\
\text { interviews }\end{array}$ & 4 weeks & $\begin{array}{l}\text { Students employed different strategies to } \\
\text { initiate conversation } \\
\text { Students used the dialogue journals for } \\
\text { personal communicative purposes } \\
\text { Students were aware of form which } \\
\text { reflected their concern for correctness } \\
\text { Through the survey, most students said } \\
\text { that dialogue journals helped them } \\
\text { develop or improve their English. }\end{array}$ \\
\hline
\end{tabular}

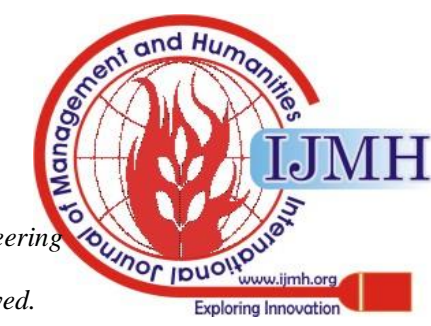


Table II: Summary of studies on the use of dialogue journal writing to improve social outcomes

\begin{tabular}{|c|c|c|c|c|c|c|c|c|c|}
\hline \multicolumn{2}{|c|}{ Article/ study } & \multirow{2}{*}{\begin{tabular}{|l}
$\begin{array}{c}\text { No/type of } \\
\text { Participants }\end{array}$ \\
16
\end{tabular}} & \multirow{2}{*}{\begin{tabular}{l} 
Research \\
\multicolumn{1}{c}{ design } \\
action \\
research
\end{tabular}} & \multicolumn{2}{|c|}{$\begin{array}{c}\text { Type of } \\
\text { Intervention }\end{array}$} & \multirow{2}{*}{$\begin{array}{l}\text { Focus of improvement } \\
\text { Writing Anxiety among } \\
\text { gifted learners }\end{array}$} & \multirow[t]{2}{*}{ Instruments } & \multirow{2}{*}{$\begin{array}{c}\begin{array}{c}\text { Intervention } \\
\text { period }\end{array} \\
14 \text { weeks }\end{array}$} & Results \\
\hline 1. & $\begin{array}{l}\text { Thevasigam } \\
\text { oney \& } \\
\text { Yunus, } \\
2013\end{array}$ & & & $\begin{array}{l}\text { Dialogue } \\
\text { writing } \\
\text { email) }\end{array}$ & $\begin{array}{r}\text { journal } \\
\text { (through }\end{array}$ & & & & $\begin{array}{l}\text { Mean scores for the Second Language Writing Anxiety Inventory } \\
\text { (SLWAI) decreased with a significant difference. }\end{array}$ \\
\hline 2. & $\begin{array}{l}\text { Alyahya, } \\
2015\end{array}$ & 55 & $\begin{array}{l}\text { descriptive/ } \\
\text { observation } \\
\text { al }\end{array}$ & $\begin{array}{l}\text { Dialogue } \\
\text { Writing }\end{array}$ & Journal & $\begin{array}{l}\text { learners attitudes and } \\
\text { perceptions }\end{array}$ & $\begin{array}{l}\text { learner's attitude } \\
\text { questionnaire and } \\
\text { follow-up interviews } \\
\text { with the learners }\end{array}$ & 4 months & $\begin{array}{l}\text { PYP learners had a highly positive attitude towards dialogue journal } \\
\text { writing in their EFL classes } \\
\text { They also have positive perceptions about the benefits of dialogue journal } \\
\text { writing as an EFL learning strategy } \\
\text { The results revealed dialogue journals as an effective EFL learning } \\
\text { strategy since they fulfil various needs for learners and instructors } \\
\text { Results also showed that Saudi university level students wrote about more } \\
\text { personal topics than academic ones in their journals }\end{array}$ \\
\hline
\end{tabular}

Table III: Summary of studies on the use of dialogue journal writing to improve social and academic outcomes

\begin{tabular}{|c|c|c|c|c|c|c|c|c|c|}
\hline \multicolumn{2}{|c|}{ Article/ study } & \multirow{2}{*}{\begin{tabular}{|c|}
$\begin{array}{c}\text { No/type of } \\
\text { Participants }\end{array}$ \\
207 \\
\end{tabular}} & \multirow{2}{*}{\begin{tabular}{l}
\multicolumn{1}{c}{$\begin{array}{c}\text { Research } \\
\text { design }\end{array}$} \\
Experimental \\
study
\end{tabular}} & \multicolumn{2}{|c|}{ Type of Intervention } & Focus of improvement & \multirow[t]{2}{*}{ Instruments } & \multirow{2}{*}{$\begin{array}{c}\begin{array}{c}\text { Intervention } \\
\text { period }\end{array} \\
10 \text { weeks }\end{array}$} & \multirow{2}{*}{$\begin{array}{l}\text { Results } \\
\text { - Dialogue journal writing is demonstrably better in improving students' } \\
\text { writing quality } \\
\text { Dialogue journaling is possibly better at improving students' reading } \\
\text { comprehension } \\
\text { Dialogue journal writing is possibly better in reducing students' writing } \\
\text { apprehension }\end{array}$} \\
\hline 1. & $\begin{array}{l}\text { Song, } \\
1997\end{array}$ & & & $\begin{array}{l}\text { Dialogue } \\
\text { writing }\end{array}$ & Journal & $\begin{array}{l}\text { 1. Writing quality } \\
\text { 2. Writing } \\
\text { apprehension } \\
\text { Reading } \\
\text { comprehension }\end{array}$ & & & \\
\hline 2. & $\begin{array}{ll}\text { Min } \& \\
\text { Kim, } \\
2005\end{array}$ & 37 & & $\begin{array}{l}\text { Dialogue } \\
\text { writing }\end{array}$ & journal & $\begin{array}{ll}\text { 1. } & \text { Writing ability } \\
\text { 2. Attitude towards } \\
\text { writing }\end{array}$ & $\begin{array}{l}\text { questionnaire } \\
\text { dialogue journal } \\
\text { entries } \\
\text { pre test and post test }\end{array}$ & 10 weeks & $\begin{array}{l}\text { more than half of the students wanted to continue dialogue journal } \\
\text { writing because this approach promoted their interest in general English } \\
\text { learning including reading comprehension } \\
\text { The mean change for the number of words was }+11.92 \text {, which suggests } \\
\text { increased writing quantity and the willingness to write } \\
\text { In the low-level group, the content and vocabulary of the post-test } \\
\text { writing sample, compared to the pre-test, were improved by } 2.9 \text { and } 4.0 \\
\text { points respectively }\end{array}$ \\
\hline 3. & $\begin{array}{l}\text { Liao \& } \\
\text { Wong, } \\
2010\end{array}$ & 41 & $\begin{array}{l}\text { Experimental } \\
\text { study }\end{array}$ & $\begin{array}{l}\text { Dialogue } \\
\text { Writing }\end{array}$ & Journal & $\begin{array}{ll}\text { 1. } & \text { Writing Fluency } \\
\text { 2. } & \text { Reflections } \\
\text { 3. } & \text { Anxiety } \\
\text { 4. } & \text { Motivation }\end{array}$ & $\begin{array}{l}\text { pre test post test } \\
\text { questionnaire }\end{array}$ & 12 weeks & $\begin{array}{l}\text { DJW project was effective in promoting the students' English writing } \\
\text { proficiency } \\
\text { the DJW project promoted the students' writing fluency, and thus they } \\
\text { could write more } \\
\text { DJW project enhanced not only the students' reflective awareness of } \\
\text { English writing but also promoted their self-growth } \\
\text { DJW project was effective in reducing the students' writing anxiety } \\
\text { DJW project was successful in promoting the students' intrinsic } \\
\text { motivation on English writing } \\
\text { the students held positive attitudes toward the DJW project }\end{array}$ \\
\hline 4. & $\begin{array}{l}\text { Yoshihar } \\
\text { a, } 2008\end{array}$ & 19 & Experimental & $\begin{array}{l}\text { Dialogue } \\
\text { Writing }\end{array}$ & Journal & $\begin{array}{l}\text { 1. Increase in number of } \\
\text { words } \\
\text { 2. positive affective } \\
\text { consequences }\end{array}$ & $\begin{array}{l}\text { dialogue journal } \\
\text { entries } \\
\text { self-report } \\
\text { questionnaire }\end{array}$ & 1 year & $\begin{array}{l}\text { The results indicated that there was no significant difference in means } \\
\text { for the total number of words from the first semester }(\mathrm{M}=456.84, \mathrm{SD}= \\
122.64) \text { to the second semester }(\mathrm{M}=482.68, \mathrm{SD}=150.34) ;(\mathrm{t}(18)=- \\
1.06, \mathrm{p}=.31) \text {. Thus, writing fluency did not statistically significantly } \\
\text { improve. } \\
\text { Many students revealed positive feelings about exchanging dialogue } \\
\text { journals with their teacher, stating it was a good opportunity and an } \\
\text { enjoyable experience. }\end{array}$ \\
\hline
\end{tabular}

\section{RESULTS AND DISCUSSION}

After following the above-mentioned procedures of conducting the systematic review, a total of twenty-two past related studies on dialogue journal writing from year 1997 to 2019 were shortlisted. Out of the twenty-two shortlisted studies, two were published between 1997 and 2003; with one publication in year 1997 and 2003. The remaining twenty articles were published between 2005 and 2019; with two in the year 2005, three in 2008, one study in 2009, two in 2010, one in 2011, two from 2012, three in 2013, one each from 2016 and 2017, followed by three from 2018 and 2019 respectively.

\section{A. Participant Characteristics}

Out of 692 participants across all studies, all were identified as English Language Learners (ELLs). 89 of the subjects in the studies were male, while 261 were female. Some studies, however, did not specify the genders of their participants. As for their language background, 19 studies were conducted with students of English as a Foreign Language (EFL) while only 3 studies involved English as a Second Language (ESL) students. 12 studies analysed outcomes for tertiary level ELLs, either college or university students while the number of studies that examined the results for secondary and primary level ELLs were 7 and 4 respectively. Pertaining to participants' $L_{1}$ background, research subjects from 7 studies spoke Bahasa Indonesia. One study included a mixture of participants from Oaxacan, Argentinian, Spanish and Mexican $\mathrm{L}_{1}$ backgrounds. Participants from a Taiwanese and American native English background were represented in one study each, while Japanese and Arabic $\mathrm{L}_{1}$ participants were involved in 2 studies each. 4 studies examined students of Iranian background. 2 studies were conducted in a Malaysian context which has various $\mathrm{L}_{1}$ such as Malay, Mandarin and Tamil. However, the participants' $\mathrm{L}_{1}$ backgrounds were not specified in either study. In one study, participants were identified as gifted learners making up $2.3 \%$ of the total participants across all studies while the remaining $98.7 \%$ were all identified as normal learners of English with proficiencies in English ranging from poor to moderately high.

\section{B. Teacher/ Researcher characteristics}

A combined total of 33 teachers and researchers implemented dialogue journal writing intervention across the 23 studies examined. Out of this number, 19 were trained and professional teachers or instructors who either taught the class being studied or were employed externally to grade post tests and pre-tests. In 7 cases of action research, the researcher and the teacher are the same person. One study did not specify who implemented the intervention.

Published By:

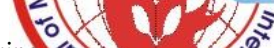
\& Sciences Publication (C) Copyright: All rights reserved.

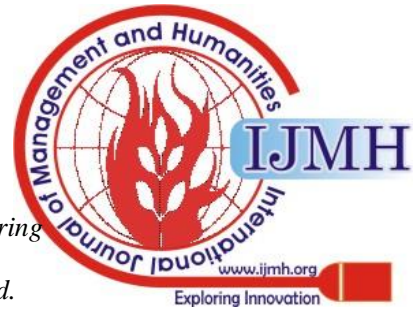


As for the background of these researchers or teachers, all the studies did not detail the education background or exact qualifications except for 2. In one study, the teachers were $\mathrm{PhD}$ candidates in applied linguistics and had teaching experience in essay writing and scoring. In another study, the two participant teachers had PhDs in literature. Only these two studies reported the teaching experience of these teachers at 5 years, 2 years and 6 years, respectively.

\section{Assessment Instruments}

Eleven studies reported using pre-tests and post-tests as instruments and out of that number, 10 specified the rubrics used for scoring. Two made use of Hemmati and Soltanpour's analytic scoring scale measuring content, grammar, organisation, vocabulary choice and spelling, while three others employed the rating scale from Jacobs et al. (1981). Other instruments included rubrics that were developed by the National Council of the Teachers of English and a qualitative writing scale known as the Wong Scale developed in 1989. Another study utilised the scoring rubrics from Ferris \& Hedgcock (1998) and one from Hedgecock \& Lefkowitz (1992). Instead of testing, 9 studies made use of observation checklists, interviews, questionnaires and analysed journal entries as means of collecting data.

\section{Research Designs}

Seven studies were in the form of action research while eleven were experimental in design, making use of a control group and experimental group. There was one case study [33]. While most studies, compared the intervention method to a baseline or in other words non-dialouge journal writing method, in two separate studies, researchers compared dialogue journal writing method to error corrected feedback [19] and topic based writing [12]. One study was identified as observational [2] and another as exploratory [34].

\section{E. Intervention}

\section{Setting and duration}

Most of the studies were conducted in the learning institution where participants were studying. However, 3 studies employed dialogue journal writing in an online setting; through WhatsApp [1] and two made use of emails; [12] and [38]. As for the duration of these studies, the longest duration was for 1 year [40] and the shortest lasted 4 weeks [20].

\section{F. Intervention Effects}

\section{Academic outcomes}

Twenty -three studies investigated the efficacy of dialogue journal writing to improve writing skills. [37] examined the effectiveness of dialogue journal writing and peer feedback in improving English writing fluency among college level ESL students and found that $64 \%$ of participants improved on grammar while $84 \%$ of participants showed improvement on spelling. [11] conducted a study to determine if directed dialogue journal writing could be used to improve English writing skills, in particular, news items. The study revealed that $92 \%$ of the 40 participants showed improvement in content writing. [19] explored the efficacy of dialogue journal writing versus error corrected feedback for improving writing proficiency in Japanese EFL students that were divided into two groups; one that had their written work corrected by the teacher and the other that received no correction . It was discovered that while dialogue journal writing was more efficient in improving overall writing ability, error corrected feedback proved more effective in improving vocabulary usage. In a separate study, [32] conducted an action research to investigate the effect of reflective dialogue journal writing on students' writing ability. The results however did not report any quantitative data on improvement but did report that participants were more inclined to share their insights and personal stories. They could also reflect and focus more on their own stumbling blocks in writing. In another study, [18] studied the effect dialogue journal writing had on writing ability of 38 EFL learners in Indonesia. Participants wrote entries based on their lessons and academic activity and at the end of 1 month, it was reported that there was a $20 \%$ increase in participants scoring from good to excellent bands, while it was also observed that there was a 53\% increase in students who took part actively in group activity. [7] also conducted a study in Indonesia involving 30 EFL students to investigate if dialogue journal writing could improve students' writing ability. Students focused on dialogue journal entries about local legend in the country. It was found that participants' mean scores in the writing post-test improved from 52.64 to 81.44 when compared to the pre-test in terms of content, organisation, vocabulary, language use and mechanics. Likewise, [24] carried out an experimental research on 50 Iranian EFL university students to investigate if dialogue journal writing had a positive impact on writing skills. After the intervention period that lasted 4 months, participants in the experimental group performed better in aspects of grammar and fluency. However, concerning the aspects of organisation, and punctuation, both experimental and control groups scored the same. In another action research conducted, [9] investigated the effect of dialogue journal writing on the writing skills of 32 EFL Indonesian high school students. After the intervention period of one month, it was discovered that the mean score of the second cycle post-test compared to the pre-test improved from 60.62 to 66.25. In addition, in the final cycle, students improved their scores to 74.37 .

Specific writing skills were also examined in some studies. Vocabulary, word choice and voice were studied in [1] who conducted the study with university level EFL students from Saudi Arabia. After the writing pre-test, participants communicated their journal entries through WhatsApp for a period of six weeks. At the end of the intervention, participants sat for a post -test and the journal entries were examined for improvement. It was discovered that mean score for vocabulary in the experimental group improved to 2.59 while the voice improved significantly with the Wilcoxon test revealing $(\mathrm{p}=.030)$. Another study that examined specific writing skills was conducted by [12] who examined the effect of dialogue journal writing (DJW) versus topic-based writing (TBW) in improving content, organisation, vocabulary, mechanics and language use. Throughout the 10-week intervention, two groups of participants underwent the two separate interventions and sat for a post-test to determine if there was any improvement. It was reported that the mean scores of both groups increased but the DJW group displayed a higher overall mean score. While the TBW group increased from, 62.59 to 68.91, the DJW group improved from 63.59 to 70.14 . The DJW group also outperformed the TBW group in aspects of content and vocabulary. However, the TBW group did better in aspects of organisation and language use.

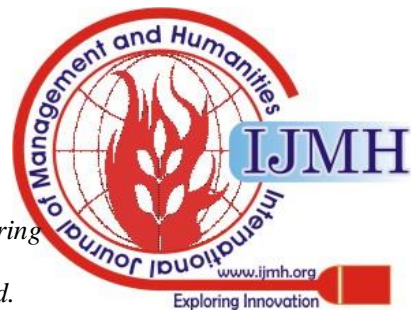


Descriptive writing skills through recount, or narratives were explored in three studies. [5] carried out a study in an Iranian high school to examine the efficacy of dialogue journal writing on descriptive writing ability in students. For six months, participants in the experimental group wrote dialogue journal entries before sitting for a post-test which revealed significant difference in the experimental group in overall writing ability and in the aspects of content, organisation and vocabulary. However, in the aspects of language use and mechanics, no significant difference was observed between both groups. In [4], high school students' narrative writing skills were the focus of improvement through the implementation of dialogue journal writing. After a period of 1 month, it was discovered that the control group only improved by 4.78 points while the mean score for the experimental group had increased by 12.02 points from the pre-test. The third study is one by [29] that examines the efficacy of dialogue journal writing to improve students recount writing skills. After the intervention period of 6 weeks, participants showed mean score improvement in terms of grammar, vocabulary, mechanics, fluency and organisation.

Word count was explored in one study by [33] who studied the effects of dialogue journal writing on writing quality and quantity. In this study, instead of communicating with the teacher or researcher, participants communicated through email with native speakers of English who were in the same age group. After a duration of 7 weeks, the dialogue journal entries were analysed, and it was reported that there was an improvement in participants' overall effectiveness of writing improvement was recorded in the aspect of language. It was also observed that participants showed increased ability to write longer entries over time. However, the increase in the number of words did not increase steadily which was attributed to participants interest in the topics written about.

Literary responses and literacy transactions were examined in two separate studies. [20] conducted an action research to find out the effectiveness of dialogue journal writing in improving language development and literary responses in Korean EFL middle school students. As it was a qualitative study, the results reported were observed at the end of 4 weeks. It was reported that participants utilised various strategies to initiate conversation and made use of the journals for personal communicative purposes. Through the survey conducted, it was gleaned that students felt that dialogue journal writing aided them to improve their English. In another study investigating dialogue journals and literacy transactions, [34] undertook an exploratory study involving 13 EFL middle school learners who were native speakers of English. Using dialogue journal entries, analysing motivation inventories and observation field notes, the study drew the following conclusions: there was evidence that journals provided an avenue that inspired students to communicate about content with others. It also reported the difference in amount written when students responded to their peers compared to the teachers which brought to light the change in authenticity of student responses based on whom they interacted with. The study concluded that dialogue journals could be employed as a diagnostic tool for writing, grammar and spelling without drawing attention to any one student.

\section{Social outcomes}

Apart from the academic outcomes that were the focus of most of the studies, six studies were conducted to investigate skills. Content saw the biggest improvement while the least

some social outcomes such as attitudes and perceptions, as well as confidence and anxiety in writing. [35] conducted as experimental study that sought to discover if dialogue journal writing could lower students' apprehension towards writing. 207 Korean EFL college students underwent the intervention for 10 weeks. To measure their apprehension, a writing apprehension scale was administered before and after treatment. Although both control group and experimental group showed reduction in apprehension, the experimental group measured a bigger change at the end of the post-test reducing the apprehension score by 4.844 points. This result however was not proven to be significant when a significance test was applied. In a separate study by [25] the effectiveness of dialogue journal writing to improve attitude towards writing. 37 Korean EFL learners participated in this study that involved writing dialogue journal entries for a duration of 10 weeks. Based on the questionnaire that was utilised in the study, it was found that more than $50 \%$ of participants wanted to continue dialogue journal writing because it encouraged their interest in reading comprehension and learning English. An increase in number of words per entry also indicated a stronger willingness to write. Similarly, [40] wanted to improve positive affective consequences through the implementation of dialogue journal writing among Japanese EFL learners in university. Apart from the dialogue journal entries, a self-report questionnaire was administered and the results were analysed. Most students reported strongly agreeing with questions on ability, quantity and confidence in expressing ideas through writing in English. Writing fluency, reflections, anxiety and motivation was the focus in another experimental study by [22] who studied the impact dialogue journal writing had on 41 Taiwanese EFL students. At the end of the 12-week intervention period, Although students' reflective awareness of English improved compared to before the intervention $(M=23.36>22.29)$, the difference in overall reflective awareness did not reach a significant level $(\mathrm{t}=1.38, \mathrm{p}=.18)$. As for anxiety in writing, the participants mean scores after the intervention decreased significantly compared to the pre-test $(\mathrm{M}=27.34<37.46)$ with $(\mathrm{t}=-5.29, \mathrm{p}=.00)$. For the aspect of motivation, when students' questionnaire scores were compared, it was reported that the mean intrinsic motivation had increased significantly $(\mathrm{M}=25.15>23.32)$. [2] conducted a study to investigate the efficacy of dialogue journal writing in relation to improving learners' attitudes and perceptions towards writing. In this observational study, 55 Arabic university EFL students were involved in dialogue journal writing for a period of 4 months. There were no quantitative results reported, only perceptions that were gleaned from the follow-up questionnaire and interviews with the participants. Participants felt that dialogue journal writing helped them express themselves in private, build a relationship with their teacher and promote reading practice and learning new vocabulary. The final study that examined social outcomes was one by [38] who wanted to investigate the effect of dialogue journal writing on writing anxiety among gifted learners. One feature that set this study apart from the rest is that the participants in this study were identified as gifted learners. Apart from that, these participants communicated via email to produce their dialogue journal entries. ublished By:

Blue Eyes Intelligence Engineering \& Sciences Publication (c) Copyright: All rights reserved. tand $\mathrm{Hu}_{\mathrm{r}} \mathrm{O}$

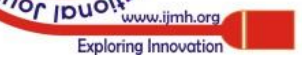


By utilising the Second Language Writing Anxiety Inventory (SLWAI), researchers were able to determine if the participants' scores decreased at the end of the intervention period. After 14 weeks of dialogue journal email writing, the mean score for SLWAI had gone down from 61.06 in the pre-test to 58.56 in the post-test, which was tested and proven to be a significant decrease.

\section{G. Discussion}

The purpose of this review was to study the impact of dialogue journal writing on students' writing skills as well as to investigate any possible positive social outcomes as a result of dialogue journal implementation in the learning environment. Findings and results across 23 studies provide a concise review of academic and social outcomes for learners who practise dialogue journal writing in over 30 years of research. Among the academic gains reported in the reviewed literature, participants were seen to improve in areas such as grammar and spelling [37], accurate vocabulary usage [19], expansion of content [11] and organisation in [5]. These results are in line with those found more than 10 years earlier; in [24] who reported improvements in the areas of grammar and overall fluency and [35] who found that dialogue journal writing not only improved students' writing quality but also their reading comprehension as a result. These benefits provide support to the theory that dialogue journal writing indeed impacts learners in a positive way and can be used as a tool in the English classroom to foster better learning of English.

Through the perspective of social outcomes, dialogue journal writing in the classroom had the ability to create meaningful teaching and learning experience [27]. Apart from that, applying this intervention in the classroom could build and strengthen the bridge of communication between the students and teacher [40]. In other words, by engaging in dialogue with the teacher, students would be given the opportunity to learn about one another that a one-way communication approach would not allow. Dialogue journals were also discovered to be a means of opening and maintaining continuous communication between educator and students [20]. This could be attributed to the back-and-forth nature of a dialogue journal that ensures an unbroken ongoing chain of correspondence. Studies also revealed that dialogue journal writing could empower learners to voice out opinions, views and feelings [14]. This could serve as an important tool to gauge if students perceive themselves to be learning well, communicate weaknesses and express their thoughts.

In line with the socio-cultural theory of learning, dialogue journal writing in the English classroom put into practice the tenets of the learning theory that is, having social and motivational context attached. This is in line, with [28] who claimed that writing is making shifts towards a more social and motivation-based setting after previously being thought of as a purely cognitive-driven process. There are four main components that determined the success in language learning and education: teacher, learner, language or culture and context. In the case of dialogue journal writing, all four of these tenets are present creating meaningful exchange and learning in the students, especially where journal topics are reflective of the participants cultural context.

Overall findings indicate that dialogue journal writing does affect language learners in a positive way by encouraging expression, independent writing and improving specific skills in writing such as organisation, vocabulary and mechanics. In the social aspect, language learners were gaining confidence, reducing anxiety and apprehension in writing after practicing dialogue journal writing.

\section{LIMITATIONS}

The most notable limitation thus far is the restricted number of studies that have been conducted in this area of research. For a more wholistic understanding to be gained about the potential benefits of this method of intervention, a larger number of studies must be analysed and reviewed.

Furthermore, in the production of a systematic review, selection and publication bias pose a potential threat to the validity and reliability of the study. Publication bias may arise when there is selection or publication of a study depending on its results. [35]. If unchecked, this bias will cause overestimation of intervention effects which can render existing evidence unreliable for drawing conclusions [10]. In order to reduce this bias, a wider selection of studies from published and unpublished sources need to be included. Avoiding limiting the outcome in the search such as including informal sources like abstracts and theses will help to reduce the occurrence of selection bias.

Another limitation and implication for the future research is to overcome the limited research designs chosen for the review. Action research designs made up $30 \%$ of the sources of literature included in this systematic review. While this form of research is a reliable source of information, its lack of generalizability may be concern when drawing conclusions about the study outcomes. In order to increase the validity of the research, studies with larger groups of participants should be sourced and included. Finally, the duration for future studies should be increased to yield more conclusive results regarding improvement or learning gains by participants.

\section{CONCLUSION AND IMPLICATIONS FOR PRACTICE}

Dialogue journal writing can benefit both students and teachers as it can be seamlessly integrated into the current curricula. Teachers can implement this intervention as a teaching method easily to large or smaller class sizes. Corresponding in a dialogue with the teacher creates a stress-free environment to practice writing. In addition, it provides the opportunity for teachers to model good language in a functional and practical setting. Finally, dialogue journal writing promotes autonomous learning and student independence.

Hence, there is a need for in-service and trainee teachers to continue the paradigm shift away from rigid form-focused writing instruction to a more communicative approach to teaching writing. The studies in this review are a clear indicator of the potential that dialogue journal writing has to improve students' written expression and language fluency on the whole. By taking into consideration, the limitations of the studies, it is imperative the more effort should be channelled into increasing the quality and narrowing the research gaps identified through this systematic review.

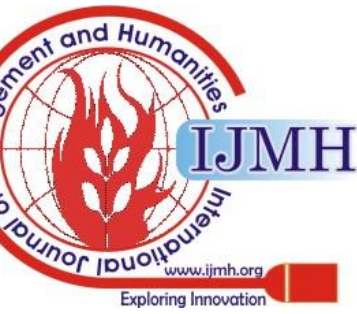




\section{REFERENCES}

1. Alsaleem, B. I. A. 2013. The Effect of "WhatsApp" electronic dialogue journaling on improving writing vocabulary word choice and voice of EFL undergraduate Saudi students. Arab World English Journal 4(3): $213-225$.

2. Alyahya, A. 2015. Dialogue journals as an EFL learning strategy in the preparatory year program: Learners' attitudes and perceptions. World Academy of Science, Engineering and Technology International Journal of Cognitive and Language Sciences 9(1): 322 - 327.

3. Barnard, R. \& Campbell, L. 2005. Sociocultural theory and the teaching of process writing: the scaffolding of learning in a university context. The TESOLANZ Journal 13: 76-88.

4. Basiswi, G. Wulyani, A. N. 2012. The effectiveness of a dialogue journal in improving students' writing skill in narrative text of the eleventh graders. English Language Education Journal. 2(2): 1-8.

5. Dabbagh, Ali. 2017. The effect of dialogue journal writing on EFL learners' descriptive writing performance: A quantitative study. International Journal of Applied Linguistics \& English Literature 6(3).

6. Datzman, K. 2012. Using dialogue journals to improve writing for English language learners. The Journal of the Arkansas Reading Association, 37(1).

7. Darmayenti. 2018. Dialogue journal writing in building students' awareness on local wisdom and English writing skill. Advances in Social Science, Education and Humanities Research 302: 195 - 199.

8. Darus, S. \& Subramaniam, K. 2009. Error analysis of the written English essays of secondary school students in Malaysia: A Case Study. European Journal of Social Sciences 8(3): 483 - 495.

9. Desiyana, E. R. 2016. Improving students' writing skill using dialogue journal technique. Jurnal Karya Ilmiah Mahasiswa Progdi Pendidikan Bahasa Inggris FKIP 2(1).

10. Dwan, K. et al. (2008) Systematic review of the empirical evidence of study publication bias and outcome reporting bias. Retrieved from https://journals.plos.org/plosone/article/authors?id=10.1371/journal.po ne.0003081

11. Fatoni, M. 2019. An Analysis Of Directed Dialogue Journal To Improve Writing Skill On News Items Texts For Indonesian EFL University Students. Jurnal Pendidikan Edutama 6(1): 1 - 9.

12. Foroutan, M., Noordin, N., \& Gani bin Hamzah, M.S. 2013. How can dialogue journal writing improve learners' writing performance in the English as a second language context? IOSR Journal of Humanities and Social Science 7(2): 35-42.

13. Ghabool, N., Mariadass, E. M. \& Seyyed H. K. 2012 . Investigating Malaysian ESL students' writing problems on conventions, punctuation, and language use at secondary school level. Journal of Studies in Education 2(3): 130- 143.

14. Ghajar, S. S. G \& Mirhosseini, S. A. 2005. English class or speaking about everything class? dialogue journal writing as a critical EFL literacy practice in an Iranian High School. Language, Culture and Curriculum 18(3)

15. Haynes-Mays, I., Peltier-Glaze, B. M. \& Broussard, S. L. 2011. The status of dialogue journal writing as a methodology for the literacy and language development of African American students. ECI Interdisciplinary Journal for Legal and Social Policy 1(1): 41-53.

16. Herrero, A. H. 2007. Journals: a tool to improve students' writing skills. Investigative News in Education 7(1), 1-37

17. Isabell, V. 2010. Dialogue journals: a way to encourage emergent writers. Senior Honors Thesis. Eastern Michigan University.

18. Janah, M. 2018. Dialogue journals as a collaborative learning technique (COLT) for teaching writing. Jurnal SMART 4(2): $107-117$.

19. Johnson, S. \& Cheng, B. 2019. The effectiveness of dialogue journal writing on the writing ability of Japanese Learners of English. Language, Culture and Communication. 11, 97 - 128.

20. Kim, H. R. 2003. Dialogue Journal Writing through a literature based approach in an EFL setting. English Teaching 58(4): 293 - 318.

21. Kitchenham, B. 2004. Procedures for performing systematic reviews. Technical Report. Department of Computer Science, Keele University and National ICT.

22. Liao, M. T. \& Wong, C. T. 2010. Effects of dialog journals on L2 students'writing fluency, reflections, anxiety, and motivation. Reflections on English Language Teaching 9(2): 139-170.

23. Linnell, K. M. 2010. Using Dialogue Journals to Focus on Form. Journal of Adult Education Information Series 1(39): 23 -28.

24. Mehrdad, A. G. 2008. The effect of dialogue journal writing on EFL students' writing skill. The Journal of Applied Linguistics, Tabriz Islamic Azad University 1(1): 34-44.

25. Min, C., \& Kim, J. 2005. The effects of dialogue journal writing on Korean high school EFL writing education. English Teaching 11(2): 71-86.

6. Ministry of Education. (2018). Curriculum Specifications. Retrieved from http://www.moe.gov.my/bpk/sp_hsp/bi/kbsm/hsp_bi_f4.pdf

Mirhosseini, S. A. 2009. For our learn of English: dialogue journa Physiotherapy 24(1): 40-48

28. Mohammad, R. \& Elmira, N. 2013. The effect of strategies-based instruction on the improvement of EFL learners' writing quality: A sociocultural approach. London: SAGE Publications Ltd.

Muflikhati, A. 2012. Improving students' writing skills on recount texts SMA IT Abu Bakar Yogyakarta in the academic year of 2012/2013. Tesis Sarjana Pendidikan, Faculty of Languages and Arts, State University of Yogyakarta.

Nesamalar, Saratha \& Teh 2005. ELT Methodology Principles and

. Nor, H.J., Norsimah, M.J., \& Kesumawati, A.B. 2008. The mastery of 106-119.

32. Pane, I. I. I., Oktora, M. \& Novita, N. 2018. The implementation of dialogue journals on writing subject at English language education program in Universitas Negeri Medan. Jurnal Generasi Kampus 11(1): $84-96$.

33. Rezaei, M., \& Manzari, E. 2011. A post-process approach: E-mail dialogue journal writing and its impact on quality and quantity of high school students' writing. Indonesian Journal of English Language Teaching 7(1): 19-30.

34. Sigmon, M. L. 2016. Dialogue journals: literacy transactions of fourth-grade students. Doctor of Philosophy dissertation, Virginia Polytechnic Institute and State University.

35. Song, M. 1997.The effect of dialogue journal writing on writing quality, reading comprehension and writing apprehension of EFL college students http://www.eric.ed.gov

36. Staton, J. \& Peyton, J. K. 1996. Dialogue journals in the multilingual classroom : building language fluency and writing skills through written interaction. Westport: ABC-CLIO

7. Stone, S. L. 2019. Promoting English Fluency through Peer Feedback Education thesis, Humboldt State University. dialogue journal writing (EDJW) and writing anxiety among gifted learners. Social and Behavioral Sciences 123: 266 - 271.

a. O 2011. Journal keeping in an ESL classroom: an innovative proach in language learning. Journal of Education and Practice 2(6): 59-64.

. Yoshihara, R. 2008. The bridge between students and teachers: The effect of dialogue journal writing. The Language Teacher 32(11): 3-7. 